UDK 51-76, 613

\title{
CALCULATION OF SUPPLEMENTARY MORBIDITY AND MORTALITY THROUGH EVOLUTIONARY MODELING OF PUBLIC HEALTH RISK
}

\author{
D.A. Kiryanov, M.R. Kamaltdinov \\ FBSI "Federal Scientific Center for Medical and Preventive \\ Health Risk Management Technologies", \\ Perm, 614045, Russia
}

\begin{abstract}
The algorithm of population quantitative estimates for additional morbidity and mortality, corresponding to the risk of disorders of the relevant functions of organs and systems of the human body, has been developed based on an evolutionary model. At each stage of the algorithm the necessary data sources, methods of treatment and intermediate results are described in detail, the method takes into account the peculiarities of age distribution of health indicators using Severity Index. Testing of the method is performed on the example of the complex influence of diverse environmental factors on several critical organs and systems. The calculation results show that the additional risk of morbidity and mortality due to diseases of almost all classes and systems increases with age, taking the invalid values in the above working age. In addition, the structure of the additional risks demonstrates overbalance of conditions associated with disorders of blood circulatory system. The results of risk assessment according to the proposed algorithms can serve as a basis for additional studies of environmental factors impacting on health, organization of health prevention and control and monitoring events.

Key words: assessment of additional morbidity and mortality, evolutional modeling, risk of disorder of functions of organs and systems.
\end{abstract}

Introduction of public risk assessment guidelines based on evolution-based modelling [8] into the work of Rospotrebnadzor agencies and organizations made it possible to improve the risk assessment methodology and increase the range of objectives. The newly developed methods result from the adaptation of the fundamental human organs and systems disorder accumulation under exposure to environmental factors to the use in practice [4]. The main advantage of evolution-based models for risk assessment is the possibility to estimate the accumulation of negative effects risk in the form of human organs and systems disorders associated with environmental exposure. This method is generally aimed at the assessment of individual risk and, secondly, at making calculations for the population at large though the latter is more on demand for the purposes of health risk management. A series of publications devoted to the use of evolution-based models for risk assessment describe the approaches to calculating the incidence of diseases and death cases related to environmental exposure [3, 6-7]. Along with this, the materials that they contain do not have clear algorithms to describe the data sources and data processing methods to assess the risk for the population. For this reason, it is important to develop an algorithm for the quantitative assessments of additional morbidity and death rates

\footnotetext{
(C) Kiryanov D.A., Kamaltdinov M.R., 2014

Kiryanov Dmitry Aleksandrovich - Candidate of Technical Sciences, Head of Department of Mathematical Modeling of Systems and Processes (e-mail: kda@fcrisk.ru; phone: +7 (342) 237-18-04).

Kamaltdinov Marat Reshidovich - junior research associate (e-mail: kmr@fcrisk.ru; phone.: +7 (342) 237-18-04).
} 
Scientific and methodological approaches to risk analysis

corresponding to the risks of human organs and systems disorders calculated using evolutionbased models.

Evolution-based models use the term 'risk' in its international meaning to indicate the combination of a risk level and its probability [1]. These models give an option to conduct dynamic assessments of the risk of functional disorders related to prolonged environmental exposure $[3,5]$.

[At that, risk was presented as a non-dimensional quantity in the range $[0 ; 1]$. On the one hand, the risk value that equals $0(\mathrm{R}=0)$ corresponds with the absence of functional disorders in a human body and, consequently, absence of the cases of diseases and deaths. On the other hand, approximation of the risk value to one $(\mathrm{R} \rightarrow \mathrm{1})$ corresponds with the increase in the frequency of heavy diseases and deaths.

Evolution-based models adjusted for various risk calculations in the form of recurrent ratios are shown in the formula (1):

$$
R_{t+1}^{i}=R_{t}^{i}+\left(\alpha_{i} R_{t}^{i}+\sum_{j} \Delta R_{t}^{i j}\right) C
$$

where $R_{t+1}^{i}$ - risk of disorder in the i body system at the moment of time $\mathrm{t}+1 ; R_{t}^{i}$ - risk of disorder in the I body system at the moment of time $t$; $\alpha \mathrm{i}$ - coefficient that takes into account the evolution of risk due to natural factors; $\mathrm{C}$ - temporary empirical coefficient depending on the average time.

We used the value of additional risk determined by environmental factors and calculated as the difference of risks under exposure and zero exposure at any specific time - as a value that describes the contribution of factors in the evolution of risk:

$$
\Delta R_{t}^{i}=R_{t}^{i}-R_{t}^{i / \hat{o}},
$$

where $\mathrm{t}$ - age group with a 5 -year interval; $\Delta R_{t}^{i}$ - additional risk of disorder in the i organ systems at the age t; ${ }^{R_{t}^{i}}$ - risk of disorder of the i organ system under environmental exposure at the age $R_{t}^{i / \hat{o}}$ - risk of disorder of the i organ system under zero environmental exposure at the age t.

Assessment of individual risk is carried out using the scale as shown in [5]. The scale allows the risk by category from permissible to very high. However it is important to conduct the population assessment not only by risk category but also by number of additional cases of health disorders differentiated by severity (in the form of diseases and deaths) at any specific time. 
Scientific and methodological approaches to risk analysis

A general algorithm for the quantitative assessment of additional cases of diseases and deaths associated with the dysfunction risk is based on the analysis of the age distribution of health indicators and includes subsequent execution of several stages (Figure 1).

Stage 1. Calculation of the risk of organ and system dysfunction with (no) account for environmental and lifestyle factors $\left(R_{t}^{i}, R_{t}^{i / \hat{0}}\right)$.

Stage 2. Assessment of the average population disease severity indicator gi in relation to organs and systems dysfunction. Assessment of the severity of diseases is based on the comparison of expert assessments and data provided by the local Compulsory Medical Insurance Foundation.

Stage 3. Calculating the average population organ and system dysfunction risk $\left(\bar{R}_{t}^{i}\right)$ based on the data on the morbidity and death rates with the account for the disease severity.

Stage 4. Building a system of reduced disease and death indicators $\tilde{z}_{t}^{i j}$ and $\tilde{s}_{t}^{i j}$ corresponding with the evolution curve of health risk accumulation under zero environmental exposure.

Stage 5. Building a system of the estimated disease and death indicators $z_{t}^{i j}$ and $s_{t}^{i j}$ corresponding with the evolution curve of health risk accumulation under environmental and lifestyle factors.

Stage 6. Calculation of the additional cases of diseases and deaths $\left(\Delta z_{t}^{i j}\right)$ and $\left(\Delta s_{t}^{i j}\right)$ related to the risk of dysfunction accumulation.

Population risk assessments are conducted with the use of the disease severity indicator that allows the comparison of various nosological forms and acts as a weight coefficient under the addition of the frequency of diseases and deaths [9]. The disease severity indicator is normalized from 0 to 1 ; given that, minor illnesses are described by the value of severity coefficient that is close to 0 , and serious diseases - close to 1 . The average population disease severity indicator is calculated based on the morbidity data and expert assessments of the severity of the most common (representative) diseases. For example, severity of URTI is assessed as 0.1 ; non-infectious gastroenteritis and colitis - as 0.35 ; cardiac angina -0.70 ; malignant growth in the brain -0.95 . It should be noted that the group of experts included 10 practicing general physicians with at least 5 years of professional experience. Such requirements to the experts are determined by the need for an objective assessment of the severity of representative diseases. 
Scientific and methodological approaches to risk analysis

\begin{tabular}{|c|c|c|}
\hline $\begin{array}{l}\text { Stage 1. Calculation of the risk of } \\
\text { organ and system dysfunction with } \\
\text { (no) account for environmental and } \\
\text { lifestyle factors } \\
\left(R_{t}^{i}, R_{t}^{i / \phi}\right)\end{array}$ & $\begin{array}{l}\text { Used data: } \\
\text { Exposure of factors }\end{array}$ & $\begin{array}{l}\text { Results: } \\
\text { Risk distribution by age } \\
\left(R_{t}^{i}, R_{t}^{i / \phi}, \Delta R_{t}^{i}\right)\end{array}$ \\
\hline $\begin{array}{l}\text { Stage 2. Assessment of the average } \\
\text { population disease severity indicator } \\
g_{i} \\
\text { in relation to organs and systems } \\
\text { dysfunction. }\end{array}$ & $\begin{array}{l}\text { Used data: } \\
\text { Morbidity Register of the } \\
\text { Compulsory Medical Insurance } \\
\text { Foundation } \\
\text { Expert assessments of the severity }\end{array}$ & $\begin{array}{l}\text { Results: } \\
\text { Assessment of the disease severity } \\
\text { for all the nosological forms gi }\end{array}$ \\
\hline $\begin{array}{l}\text { Stage 3. Calculation of the average } \\
\text { population organ and system } \\
\text { dysfunction risk }\left(\bar{R}_{t}^{i}\right)\end{array}$ & \begin{tabular}{ll}
\multicolumn{3}{l}{ Used data: } \\
$-\quad \quad \quad$ Disease registry of the \\
Federal (TFCMI) \\
$-\quad$ Death rate (form №C51) \\
- & Population (table 2PH) \\
- & Disease severity gi
\end{tabular} & $\begin{array}{l}\text { Results: } \\
\text { Age distribution of the general } \\
\qquad\left(\bar{R}_{t}^{i}\right) \\
\text { population risk }\end{array}$ \\
\hline $\begin{array}{l}\text { Stage 4. Building of the system of } \\
\text { reduced disease and death } \\
\qquad \widetilde{Z}_{t}^{i j} \widetilde{S}_{t}^{i j} \text { and }\end{array}$ & $\begin{array}{l}\text { Used data: } \\
\text { Age distribution of risk } \\
\qquad\left(\bar{R}_{t}^{i}, R_{t}^{i / \phi}\right) \\
\text { indicators }- \\
-\quad \text { Disease registry of the } \\
\text { Federal (TFCMI) } \\
-\quad \text { Death rate (form №C51) }\end{array}$ & $\begin{array}{l}\text { Results: } \\
\text { Age distribution of the indicators } \\
\widetilde{Z}_{t}^{i j}, \widetilde{S}_{t}^{i j}\end{array}$ \\
\hline $\begin{array}{l}\text { Stage 5. Building of the system of } \\
\text { estimated disease and death } \\
\qquad \widetilde{Z}_{t}^{i j} \widetilde{S}_{t}^{i j} \text { and }\end{array}$ & $\begin{array}{l}\text { Used data: } \\
\text { Age distribution of the } \\
\text { average population risk with the } \\
\text { account for (zero) environmental } \\
\qquad\left(R_{t}^{i}, R_{t}^{i / \phi}\right) ; \\
\text { exposure } \\
\qquad \widetilde{Z}_{t}^{i j}, \widetilde{S}_{t}^{i j} \\
\text { Age distribution of } \\
\text { indicators }\end{array}$ & $\begin{array}{l}\text { Results: } \\
\text { Age distribution of the indicators } \\
\widetilde{Z}_{t}^{i j}, \widetilde{S}_{t}^{i j}\end{array}$ \\
\hline $\begin{array}{l}\text { Stage 6. Calculation of the } \\
\text { additional cases of diseases } \\
\left(\Delta z_{t}^{i j}\right) \text { and deaths }\left(\Delta s_{t}^{i j}\right)\end{array}$ & $\begin{array}{l}\text { Used data: } \\
\text { Age distribution of reduced and } \\
\text { calculated disease and death } \\
\qquad \widetilde{z}_{t}^{i j}, z_{t}^{i j} \\
\text { indicators } \\
\widetilde{S}_{t}^{i j}, s_{t}^{i j}\end{array}$ & $\begin{array}{l}\text { Results: } \\
\text { Age distribution of the indicators } \\
\Delta z_{t}^{i j}, \Delta s_{t}^{i j}\end{array}$ \\
\hline
\end{tabular}

Figure 1. A general algorithm for the quantitative assessment of additional cases of diseases and deaths associated with the dysfunction risk 
Scientific and methodological approaches to risk analysis

Determination of the severity of the rest of the diseases is based on comparison with the representative disease by the duration of treatment. By so doing, the function of recalculating should meet the following requirements:

- severity of a disease is characterized by the duration of treatment;

- absence of disease corresponds with the absence of severity;

- severity of a disease is always less than one.

Taking into account the above requirements for the calculation of disease severity values, use the following ratios for the disease subclass:

$$
g_{i}=1-e^{T_{i} \frac{\ln \left(1-g_{M}\right)}{T_{M}}},
$$

where $\mathrm{gM}$ и $\mathrm{TM} \mathrm{-} \mathrm{value} \mathrm{of} \mathrm{the} \mathrm{severity} \mathrm{and} \mathrm{average} \mathrm{duration} \mathrm{of} \mathrm{a} \mathrm{representative} \mathrm{disease;} \mathrm{gi} \mathrm{and}$ $\mathrm{Ti}$ - calculated value of severity and average duration of $\mathrm{i}$ disease.

With the help of severity coefficient based on the disease and death rates distribution by age, we determine a reduced system of population health indicators which includes an age distribution of population disease and death rate indicators that correspond with the background evolution health risk curve.

At the same time, for each age group, we determine an indicator that corresponds with the average population organ and system dysfunction, using the following ratio:

$$
\bar{R}_{t}^{i}=\frac{\sum_{j} \bar{z}_{t}^{i j} g^{j}+\bar{s}_{t}^{i}}{1000},
$$

where $t$ - age group with a 5-year interval; $\bar{R}_{t}^{i}$ - indicator that corresponds with the average population health disorder risk in the $i$ system or organ at the age $t ; \bar{z}_{t}^{i j}$ - average population morbidity for the $j$ disease and $i$ system or organ at the age $t$ (cases per 1000); $\bar{s}_{t}^{i}$ - average population death rate from the disorders of the $i$ system or organ at the age $t$ (cases per 1000); $g^{j}-$ severity coefficient.

Based on the ration between the indicators corresponding with the average population dysfunction risk, the calculated health risk under exposure to the factors under study and the background evolution health risk curve, we calculated the reduction coefficients:

$$
k_{t}^{i}=\frac{R_{t}^{i / \hat{o}}}{\bar{R}_{t}^{i}}, \quad l_{t}^{i}=\frac{R_{t}^{i}}{R_{t}^{i / \hat{o}}} .
$$

The reduced and calculated system of the population morbidity and death rate indicators is determined based on the following ratio: 
Scientific and methodological approaches to risk analysis

$$
\begin{aligned}
\tilde{z}_{t}^{i j} & =\bar{z}_{t}^{i j} \cdot k_{t}^{i} & z_{t}^{i j} & =\tilde{z}_{t}^{i j} l_{t}^{i} \\
\tilde{s}_{t}^{i j} & =\bar{s}_{t}^{i j} \cdot k_{t}^{i}, & s_{t}^{i j} & =\tilde{s}_{t}^{i j} l_{t}^{l^{i}},
\end{aligned}
$$

where $\widetilde{z}_{t}^{i j}, z_{t}^{i j}$ - reduced and calculated morbidity for the $\mathrm{j}$ disease of the i system at the age $\mathrm{t}$; $\widetilde{S}_{t}^{i j}, S_{t}^{i j}-$ reduced and calculated morbidity for the $\mathrm{j}$ disease of the $\mathrm{i}$ system at the age $t$.

Additional morbidity and death rate are calculated as the difference between the calculated and reduced values:

$$
\begin{aligned}
& \Delta z_{t}^{i j}=z_{t}^{i j}-\tilde{z}_{t}^{i j} \\
& \Delta s_{t}^{i j}=s_{t}^{i j}-\tilde{s}_{t}^{i j},
\end{aligned}
$$

where $\Delta z_{t}^{i j}$ - additional rate of $\mathrm{j}$ disease concerning i system at the age $\mathrm{t}$, $\Delta s_{t}^{i j}$-additional death rate from $\mathrm{j}$ disease concerning $\mathrm{i}$ system at the age $\mathrm{t}$.

We tested new methods to calculate additional cases of diseases and deaths corresponding with the risk of dysfunction based on the results of evolution-based modelling of the health risk under environmental exposure determined by the level of exposure presented in Table 1.

The example describes combined exposure to heterogeneous factors of several critical organs and systems. Such situations are typical of the urban areas located in close proximity to industrial enterprises and characterized by various social issues.

The results of the risk assessment conducted with the use of evolution-based modelling are presented in Table 2 .

Additional risk becomes impermissible in the age groups of 45+. Here, the main disorders concern the cardiovascular system. Impermissible risk of disorders of other systems begins to develop after the age of 60 .

The obtained values of additional dysfunction risk are in line with the additional cases of diseases and deaths as shown in Tables 3 and 4.

The tables contain the values of the calculated morbidity and death rate that correspond with the additional dysfunction risks. Since the circulatory system as affected most of all, the composition of additional morbidity and death rate shows excess of conditions associated with cardiovascular disorders. The dynamic patter of the values of additional morbidity and death rate associated with the dysfunction risks is shown in Figure 2. 
The range of exposure values determined by environmental factors

\begin{tabular}{|l|c|c|}
\hline \multicolumn{1}{|c|}{ Factor } & Factor parameters & Permissible level \\
\hline Nitrogen oxide in the atmospheric air, $\mathrm{mg} / \mathrm{m}^{3}$ & $0,022-0,127$ & 0,04 \\
\hline Carbonic oxide in the atmospheric air, $\mathrm{mg} / \mathrm{m}^{3}$ & $3,5-5,33$ & 3,0 \\
\hline Cadmium in drinking water, $\mathrm{mg} / \mathrm{dm}^{3}$ & $0,00038-0,00041$ & 0,00002 \\
\hline Noise, dBA & 55,72 & 50 \\
\hline Smoking, mg of nicotine/day & $0-10$ & 0,1 \\
\hline Alcohol consumption, g/week & $0-50$ & 30 \\
\hline Physical activity, min/week & $200-60$ & He менее 200 \\
\hline
\end{tabular}

Table 2

Additional dysfunction risk associated with environmental exposure

\begin{tabular}{|l|c|c|c|c|c|c|c|}
\hline Age, years old & $\begin{array}{c}\text { Urinary } \\
\text { system } \\
\text { diseases }\end{array}$ & $\begin{array}{c}\text { Central } \\
\text { nervous } \\
\text { system } \\
\text { diseases }\end{array}$ & $\begin{array}{c}\text { Respiratory } \\
\text { diseases }\end{array}$ & $\begin{array}{c}\text { Digestive tract } \\
\text { diseases }\end{array}$ & $\begin{array}{c}\text { Circulatory } \\
\text { system diseases }\end{array}$ & $\begin{array}{c}\text { Ear and } \\
\text { mastoid bone } \\
\text { diseases }\end{array}$ & $\begin{array}{c}\text { Endocrine } \\
\text { system } \\
\text { diseases }\end{array}$ \\
\hline from 20 to 24 & 0,001 & 0,003 & 0,001 & 0,001 & 0,004 & 0,004 & 0,002 \\
\hline from 25 to 29 & 0,001 & 0,003 & 0,002 & 0,002 & 0,008 & 0,004 & 0,003 \\
\hline from 30 to 34 & 0,002 & 0,006 & 0,004 & 0,003 & 0,012 & 0,006 & 0,005 \\
\hline from 35 to 39 & 0,003 & 0,009 & 0,007 & 0,006 & 0,022 & 0,007 & 0,008 \\
\hline from 40 to 44 & 0,008 & 0,015 & 0,01 & 0,013 & 0,042 & 0,009 & 0,016 \\
\hline from 45 to 49 & 0,015 & 0,026 & 0,014 & 0,026 & 0,077 & 0,011 & 0,028 \\
\hline from 50 to 54 & 0,021 & 0,037 & 0,017 & 0,041 & 0,131 & 0,012 & 0,045 \\
\hline from 55 to 59 & 0,029 & 0,049 & 0,022 & 0,057 & 0,213 & 0,015 & 0,068 \\
\hline from 60 to 64 & 0,036 & 0,061 & 0,027 & 0,074 & 0,338 & 0,018 & 0,096 \\
\hline from 65 to 69 & 0,043 & 0,074 & 0,033 & 0,093 & 0,527 & 0,021 & 0,136 \\
\hline from 70 to 74 & 0,051 & 0,087 & 0,04 & 0,114 & 0,478 & 0,024 & 0,189 \\
\hline 75 and older & 0,059 & 0,102 & 0,047 & 0,137 & 0,209 & 0,028 & 0,26 \\
\hline
\end{tabular}

Table 3

\section{Additional morbidity by classes related to the main organs and systems (number of cases per 1000 population)}

\begin{tabular}{|l|c|c|c|c|c|c|c|}
\hline Age, years old & $\begin{array}{c}\text { Urinary } \\
\text { system } \\
\text { diseases }\end{array}$ & $\begin{array}{c}\text { Central nervous } \\
\text { system diseases }\end{array}$ & $\begin{array}{c}\text { Respiratory } \\
\text { diseases }\end{array}$ & $\begin{array}{c}\text { Digestive tract } \\
\text { diseases }\end{array}$ & $\begin{array}{c}\text { Circulatory } \\
\text { system diseases }\end{array}$ & $\begin{array}{c}\text { Ear and } \\
\text { mastoid bone } \\
\text { diseases }\end{array}$ & $\begin{array}{c}\text { Endocrine } \\
\text { system } \\
\text { diseases }\end{array}$ \\
\hline from 20 to 24 & 1,100 & 5,439 & 8,130 & 5,814 & 7,868 & 14,919 & 6,720 \\
\hline from 25 to 29 & 2,393 & 8,686 & 16,718 & 12,803 & 13,474 & 18,872 & 11,302 \\
\hline from 30 to 34 & 4,451 & 13,012 & 28,395 & 22,821 & 23,290 & 23,600 & 19,622 \\
\hline from 35 to 39 & 7,410 & 19,292 & 42,817 & 35,387 & 40,017 & 28,993 & 32,214 \\
\hline from 40 to 44 & 16,294 & 33,837 & 53,431 & 83,637 & 74,395 & 32,918 & 60,165 \\
\hline from 45 to 49 & 31,504 & 56,094 & 63,399 & 159,187 & 136,497 & 36,872 & 107,370 \\
\hline from 50 to 54 & 47,113 & 80,762 & 73,005 & 233,773 & 229,765 & 41,816 & 168,711 \\
\hline from 55 to 59 & 62,712 & 109,388 & 78,743 & 308,362 & 366,589 & 46,605 & 248,464 \\
\hline from 60 to 64 & 78,063 & 135,221 & 87,266 & 393,629 & 576,665 & 55,014 & 353,359 \\
\hline from 65 to 69 & 91,873 & 157,646 & 100,359 & 493,202 & 886,424 & 59,313 & 495,415 \\
\hline from 70 to 74 & 107,419 & 181,616 & 115,645 & 594,794 & 1052,728 & 65,513 & 684,385 \\
\hline 75 and older & 124,309 & 224,206 & 135,220 & 648,903 & 549,218 & 63,479 & 932,231 \\
\hline
\end{tabular}


Table 4

Additional deaths by cause corresponding with the main organs and systems (number of cases per 1000 population)

\begin{tabular}{|l|c|c|c|c|c|c|c|}
\hline Age, years old & $\begin{array}{c}\text { Urinary } \\
\text { system } \\
\text { diseases }\end{array}$ & $\begin{array}{c}\text { Central } \\
\text { nervous } \\
\text { system } \\
\text { diseases }\end{array}$ & $\begin{array}{c}\text { Respiratory } \\
\text { diseases }\end{array}$ & $\begin{array}{c}\text { Digestive tract } \\
\text { diseases }\end{array}$ & $\begin{array}{c}\text { Circulatory } \\
\text { system } \\
\text { diseases }\end{array}$ & $\begin{array}{c}\text { Ear and } \\
\text { mastoid bone } \\
\text { diseases }\end{array}$ & $\begin{array}{c}\text { Endocrine } \\
\text { system } \\
\text { diseases }\end{array}$ \\
\hline from 20 to 24 & 0,000 & 0,000 & 0,001 & 0,001 & 0,029 & 0,000 & 0,002 \\
\hline from 25 to 29 & 0,001 & 0,000 & 0,013 & 0,006 & 0,151 & 0,000 & 0,000 \\
\hline from 30 to 34 & 0,002 & 0,000 & 0,032 & 0,019 & 0,386 & 0,000 & 0,007 \\
\hline from 35 to 39 & 0,007 & 0,000 & 0,042 & 0,039 & 0,613 & 0,005 & 0,014 \\
\hline from 40 to 44 & 0,025 & 0,000 & 0,078 & 0,124 & 0,944 & 0,000 & 0,006 \\
\hline from 45 to 49 & 0,033 & 0,000 & 0,142 & 0,238 & 1,547 & 0,000 & 0,034 \\
\hline from 50 to 54 & 0,069 & 0,000 & 0,141 & 0,490 & 2,404 & 0,000 & 0,036 \\
\hline from 55 to 59 & 0,104 & 0,000 & 0,211 & 0,786 & 3,737 & 0,004 & 0,060 \\
\hline from 60 to 64 & 0,207 & 0,000 & 0,271 & 1,080 & 6,073 & 0,000 & 0,131 \\
\hline from 65 to 69 & 0,198 & 0,000 & 0,406 & 1,392 & 11,282 & 0,000 & 0,184 \\
\hline from 70 to 74 & 0,276 & 0,000 & 0,556 & 1,758 & 15,000 & 0,000 & 0,388 \\
\hline 75 and older & 0,405 & 0,000 & 0,827 & 2,945 & 11,079 & 0,000 & 0,640 \\
\hline
\end{tabular}

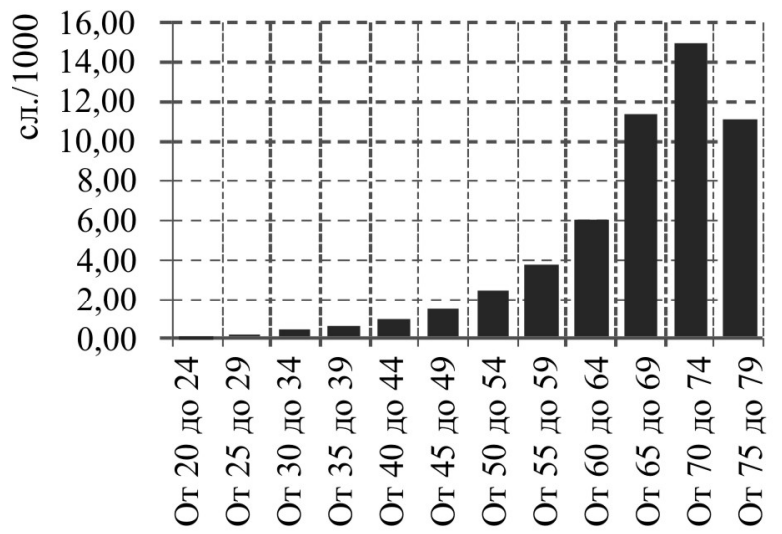

$a$

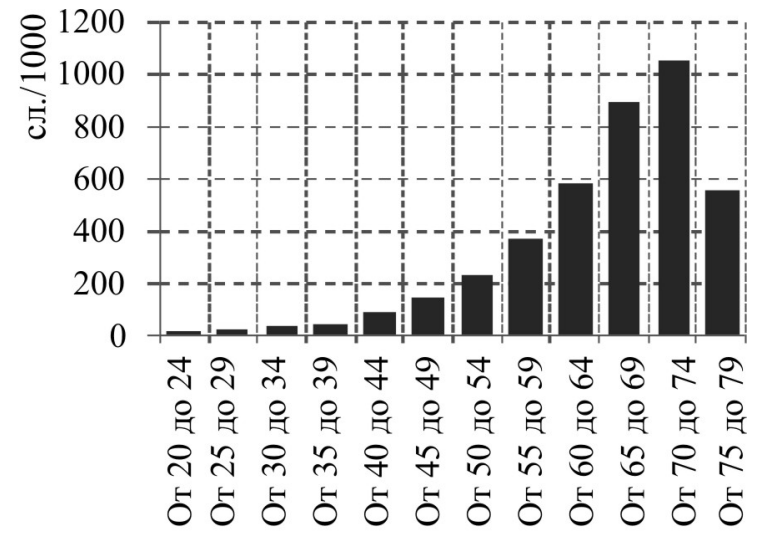

$\sigma$

Figure 2. Age distribution of population death risks associated with the circulatory system diseases (a) and circulatory system diseases (б) under exposure to environmental and lifestyle factors

The figure above shows that the age distribution of quantitative risk indicators corresponds with the main consistent patterns of age-related health disorders. The calculations showed that additional morbidity risk and deaths from diseases of various organs and systems increase with age. At an older age, additional morbidity and deaths are higher as compared to the respective indicators at a working age.

Conclusions. Consequently, the offered algorithm of the quantitative assessment of population health risks gives an opportunity to add data on the estimated additional disease and death cases related to environmental exposure to the assessment of individual risk using evolution-based models. Furthermore, the obtained results may serve as a basis for advanced 
studies of the effects of environmental factors on public health as well as the development of medical and preventative programs. Introduction of this approach into the activities of the Federal Service on Surveillance for Consumer Rights Protection and Human Well-Being may help obtain evidence on the effects of pollution sources on public health, mainly, for the purposes of preventative and supervisory programs.

\section{References}

1. Zaytseva N.V., Shur P.Z. Aktual'nye voprosy metodicheskoy podderzhki otsenki riska dlya zdorov'ya naseleniya pri obespechenii bezopasnosti produktsii: mirovoy zarubezhnyy opyt i praktika tamozhennogo soyuza [Topical issues of methodological support of public health risk assessment while ensuring the safety of products: global foreign experience and practice of the customs union]. Analiz riska zdorov'yu, 2013, no. 4, pp. 4-16.

2. Zaytseva N.V., Shur P.Z., Aminova A.I., Kir'yanov D.A., Kamaltdinov M.R. K otsenke dopolnitel'nogo riska zabolevaniy zheludochno-kishechnogo trakta, assotsiirovannykh $\mathrm{s}$ disbiozom kishechnoy mikroflory vsledstvie vozdeystviya ostatochnykh kontsentratsiy tetratsiklina $\mathrm{V}$ pishchevykh produktakh [Assessing the additional risk of diseases of the gastrointestinal tract associated with dysbiosis of intestinal microflora due to the impact of tetracycline residues in foods]. Zdorov'e naseleniya i sreda obitaniya, $\square$ 2012, no. 7, pp. 46-48.

3. Zaytseva N.V., Shur P.Z., Kir'yanov D.A., Alekseev V.B., Sboev A.S., VolkLeonovich O.P. Kolichestvennaya otsenka nekantserogennogo riska dlya zdorov'ya naseleniya [Quantitative assessment of non-cancer risk to public health]. Gigiena i sanitariya, 2008, no. 6, pp. 64-67.

4. Trusov P.V., Zaytseva N.V., Kir'yanov D.A., Kamaltdinov M.R., Tsinker M.Yu., Chigvintsev V.M., Lanin D.V. Matematicheskaya model' evolyutsii funktsional'nykh narusheniy $\mathrm{v}$ organizme cheloveka $\mathrm{s}$ uchetom vneshnesredovykh faktorov [Mathematical model for the evolution of functional disorders in the human body taking into account environmental factors]. Matematicheskaya biologiya i bioinformatika, 2012, no. 2, pp. 589-610, avaible at: http: //www.matbio.org/2012/Trusov_7_589.pdf.

5. Zaytseva N.V., Shur P.Z., May I.V., Kir'yanov D.A. Metodicheskie podkhody k otsenke integral'nogo riska zdorov'yu naseleniya na osnove evolyutsionnykh matematicheskikh modeley [Methodological approaches to the assessment of the integral health risk on the basis of mathematical models of evolution]. Zdorov'e naseleniya $i$ sreda obitaniya $\square, 2011$, no. 10, pp. 69.

6. Zaytseva N.V., Shur P.Z., Kir'yanov D.A., Kamaltdinov M.R., Tsinker M.Yu.Metodicheskie podkhody $\mathrm{k}$ otsenke populyatsionnogo riska zdorov'yu na osnove evolyutsionnykh modeley [Methodological approaches to the assessment of population health risk on the basis of evolutionary models]. Zdorov'e naseleniya $i$ sreda obitaniya, 2013, no. 1 (238), pp. 4-6.

7. Zaytseva N.V., Trusov P.V., Shur P.Z., Kir'yanov D.A., Chigvintsev V.M., Tsinker M.Yu. Metodicheskie podkhody $\mathrm{k}$ otsenke riska vozdeystviya raznorodnykh faktorov sredy obitaniya na zdorov'e naseleniya na osnove evolyutsionnykh modeley [Methodological approaches to the assessment of risk of exposure to diverse environmental factors on human health based on evolutionary models]. Analiz riska zdorov'yu, 2013, no. 1, pp. 15-23.

8. MR 2.1.10.0062-12. Kolichestvennaya otsenka nekantserogennogo riska pri vozdeystvii khimicheskikh veshchestv na osnove postroeniya evolyutsionnykh modeley [MR 2.1.10.0062-12. Quantitative assessment of non-cancer risk with exposure to chemicals on the 
Scientific and methodological approaches to risk analysis

basis of constructing evolutionary models]. Moscow: Federal'nyy tsentr gigieny i epidemiologii Rospotrebnadzora, 2012. $36 \mathrm{p}$.

9. Tsinker M.Yu., Kir'yanov D.A., Kamaltdinov M.R. Primenenie kompleksnogo indeksa narusheniya zdorov'ya naseleniya dlya otsenki populyatsionnogo zdorov'ya $\mathrm{v}$ permskom krae [Application of the complex index of health disorders for the assessment of population health in the Perm Krai]. Izvestiya Samarskogo nauchnogo tsentra Rossiyskoy akademii nauk, 2013, vol. 15, no. 3-6, pp. 1988-1992. 